\title{
Protecting Lemurs: Ecotourism
}

In their policy forum "averting lemur extinctions amid Madagascar's political crisis" (21 February, p. 842), C. Schwitzer et al. call for ecotourism, community reserves, and research stations as tools for lemur conservation. In fact, ecotourism already generates net conservation gains for at least 13 lemur species (1).

Ecotourism provides half the funds for research and captive breeding at Parc Ivoloina ( 1 ) for the critically endangered greater bamboo, blue-eyed black, and black-and-white ruffed lemur (species cited in the Policy Forum's supplementary table S1). Funds from ecotourism also pay local guides who protect the endangered Hubbard's sportive lemur near the mining town of Ilakaka, where unguarded woodland is cleared for firewood. In addition, these funds support entrance and guide fees at the community-owned Reniala Reserve on the dry southwest coast (1).

Tourism does cause some problems (1). Wildlife smugglers capture aye-ayes, release them briefly for tourists, and then recapture them. Ring-tailed lemurs at Isalo National Park are fed for the benefit of tourists. Caged captured fossas are put on show for tourists near Mantadia National Park. Lemurs on display at a rehabilitation center near Analamazaotra Nature Reserve may be captured for tourism. These concerns are not specific to Madagascar's primates. Similar exploitation concerns have been raised about orangutan rehabilitation centers in Borneo and chained captured jaguars on show to tourists in the Amazon.

On balance, however, ecotourism helps protect lemurs against logging (2-4), poaching, and bushmeat hunting $(5,6)$. Many endangered and critically endangered species worldwide rely on ecotourism revenue for conservation (7). Ecotourism works when it switches local communities from cash or subsistence consumption to tourism earnings based on conservation $(1,8,9)$.

\section{RALF BUCKLEY}

Department of Environment, Griffith University, Gold Coast, QLD 4222, Australia. E-mail: r.buckley@griffith.edu.au

\section{References}

1. R. C. Buckley, Conservation Tourism (CABI, Oxford, 2010). 
2. M. A. Barrett, J. L. Brown, M. K. Morikawa, J.-N. Labat, A. D. Yoder, Science 328, 1109 (2010).

3. M. A. Barrett, J. L. Brown, A. D. Yoder, Nature 499, 29 (2013).

4. P. H. Raven et al., Conservation Biology: Voices from the Tropics (Wiley, New York, 2013), pp. 33-39.

5. M. A. Barrett, J. Ratsimbazafy, Nature 461, 470 (2009).

6. J. H. Razafimanahakaa et al., Oryx 46, 584 (2012).

7. R. C. Buckley et al., PLOS ONE 7, e44134 (2012).

8. R. C. Buckley, H. S. Pabla, Nature 489, 33 (2012).

9. E. F. Pienaar et al., Ecol. Econ. 98, 39 (2014). 